\title{
Phoneme acquisition: Infants and second language learners
}

\section{James Jensen}

Founder, Aka-Kara English

\section{IPA and Dr. Janet Werker}

Infant phoneme acquisition (IPA) research began with researchers looking for the innate phonetic representations Chomsky hypothesized. Cross-language speech perception studies led to the investigation of speech perception in children. It was found that while adults only distinguish phonetic contrasts in their native language, infants could discriminate both native and non-native contrasts equally well. Infants can hear the sounds of any language.

Clearly, adults cannot distinguish the phonemes of every language, so the question that arose was at what age humans lose this ability. Dr. Janet Werker took up this question and hypothesized that the ability to discriminate non-native contrasts is lost at puberty. She discovered, however, that the loss occurs between 6 and 12 months of age (Werker \& Tees, 1983).

This finding has been replicated and supported by brain imaging. Cheour, et al. (1998) used MEG to confirm that the mismatch negativity (MMN) response, a measure of electrical activity in the brain, "is present in 6 month old infants for both native and nonnative contrasts, but that by 12 months of age the MMN response to the nonnative contrasts is no longer present" (Kuhl, Tsao, Liu, Zhang \& de Boer, 2001, p. 157). Werker concluded that at 10 or 11 months, infants start focusing on their native language and learn to exclude any sounds they do not frequently hear.

Werker's claim was supported by research, but as is the case with any complex paradigm, not all the results fit. Some revealing exceptions appeared. "The framework that emerges from this research," claims Patricia Kuhl (2000), "is very different

\section{Keywords}

infant language acquisition, phonemes, native language model

This paper argues for explicit phoneme perception training. It discusses infant phoneme acquisition studies and relates these studies to second language learners. The first half of the article is an account of infant language acquisition studies and uses the Native Language Model, as developed by Patricia Kuhl, to conceptualize an infant's phoneme acquisition process. The second half of this paper deals with what LI phoneme acquisition means for adult second language learners. Three questions are addressed: First, to what extent can L2 learners' perceptual patterns be modified after the initial neural commitment? Second, is phonemic training with adult learners worthwhile? And, third, what methodologies are the most effective for modifying an L2 learner's initial LI phoneme structure? The techniques discussed are contrastive exposure, making the phoneme salient, and high-variability.

本論は、明示的に行う音素認識トレーニン グについて論じる。乳幼児の音素習得研究 を論議し、これらの研究を第2言語学習者 に関連づける。前半は乳幼児の言語習得 研究の説明において、Patricia Kuhlの乳幼 児の音素習得プロセスを概念したNative Language Magnet Theoryを用いている。 後半では、乳幼児の第 1 言語音素習得が大 人である第2言語学習者にどのような意味を 持つのかを述べる。次の3点を検討する。1) 第2言語学習者の音素認識パターンは、第1 言語でのパターンが確立した後、どの程度修 正されることができるのか。2) 大人の学習 者に対する音素認識トレーニングは価値が あるのか。3)第2言語学習者における第 1 言 語の音素構造を修正するには、どのような 方法が最も効果的なのか。論議されている 手法は、音素を際立たせ、高い変動性をもた らす対照提示である。 
from that held historically. Infants are neither the tabulae rasae that Skinner described nor the innate grammarians that Chomsky envisioned" (p. 11856). Research, Kuhl claims, has discovered "a new kind of learning" (p. 11852). The data on infants' language acquisition accumulated since Werker's early work "has sent theorists back to the design board" (Kuhl, Tsao, et al., 2001, p. 145). The course that unfolds as infants tune into their native language reveals an emerging filter that operates not like a passive sieve, but more like a resonator, a filtering device that enhances as well as attenuates an input signal.

\section{The Native Language Magnet Theory}

Kuhl's Native Language Magnet Theory (NLMe) (Kuhl, Conboy, et al., 2008) holds that infants recognize and categorize sound patterns into a "sound map." By 6 months, an English speaking infant has heard hundreds of thousands of examples of the /i/ as in "daddy" and "mommy." NLM-e claims babies develop a sound map in their brains that helps them hear the / $\mathrm{i} /$ sound clearly. Babies create perfect examples of sounds with a target area around each sound. Once their sound map for $/ \mathrm{i}$ / is created babies can pick out the $/ \mathrm{i}$ / from the other sounds they hear.

These prototypes "tune" the child's brain to the native language. Kuhl claims that language experience "warps" perception. "No speaker of any language perceives acoustic reality; in each case, perception is altered in the service of language" (2000, p. 11853).

\section{The implications for EFL}

Early language development entails a shift from a language-general to a language-specific pattern of perception. This transition reflects the formation of a language-specific filter, which makes learning a second language more difficult. Kuhl, Tsao, et al. (2001) claim the creation of a sound map "commits" neural structure and this "neural commitment to a learned structure interferes with the processing of information not conforming to the learned pattern" (p. 161).

This brings up the first question asked at the outset: Can L2 learners' perceptual patterns be modified? The Critical Period Hypothesis (CPH) holds that language-learning ability is reduced after puberty due to the loss of neurological plasticity. While a full account of $\mathrm{CPH}$ is beyond this paper, some researchers believe the strictest versions are too simplistic. Some claim there are different critical periods for different language skills. Werker and Tees (2005) point out:

There is virtually no system for which some mechanism, at some level, cannot be found to allow further change beyond the point in time at which input would typically have the greatest influence. This can be seen at every level of analysis from the behavioral through the molecular. (p. 242)

For NLM-e, the early neural commitment in L1 becomes "entrenched" and causes sounds close to the prototype / i/ to be heard as an /i/. Kuhl (2000) calls this the perceptual magnet effect. Once a sound category exists in memory, "it functions like a perceptual magnet for other sounds in the category" (p. 11853). That is, the prototype attracts sounds that are similar so that they sound like the prototype itself. This is why Japanese, who do not have the prototype of the vowel of "bit" mapped in memory, tend to hear it as the vowel in "beat" which they do have mapped. This neural commitment to a learned structure interferes with the processing of information so "initial learning can alter future learning" (Kuhl, 2000, p. 11855). This entrenchment, however, is not biological.

McClelland (n. d.) agrees. Discussing a study he conducted of the $/ \mathrm{r}-1 /$ contrast by native Japanese speakers he comments:

The findings ... suggest that there is considerable residual plasticity in the phonological systems of Japanese adults. Their failure to learn under normal conditions may reflect not so much a loss of plasticity as a tendency for the mechanisms of learning to maintain strongly established perceptual tendencies. (p. 20)

The claim is that initial learning can alter future learning independent of a strict time period. This study challenges $\mathrm{CPH}$ and shows that language acquisition patterns are influenced by factors other than biological constraints.

According to NLM-e, the neural system for L2 acquisition is, as Ellis (2006) says, a "tabula replete" (p. 184). NML-e conceives this as a neural 
commitment that becomes entrenched with age and can interfere with L2 learning. While making L2 acquisition difficult, the sound map can be modified.

\section{The case for explicit phoneme instruction}

Turning to the second question asked at the outset: Is explicit phoneme training worthwhile? Quite simply, it is the only way L2 learners will ever learn to perceive difficult phonemes. They will not learn from natural communication.

According to NLM-e, the L1 sound map changes how people perceive sound. We do not hear the sounds directly, but filter them through the phonemic structure of our L1. If you can't hear it, you can't learn it!

McCandliss, Fiez, Protopapas, Conway, and McClelland (2002) claim that not only do L2 learners not hear the correct pronunciation, but "this tendency may be self-reinforcing, leading to its maintenance even when it is counterproductive" (p. 185). That is, every time a non-native listener fails to distinguish a phoneme, it actually reinforces the cause of the problem. Thinking that students will learn to hear in a "natural" and communicative setting is misguided. The "sad irony for an L2 speaker is that more input simply compounds their error; they dig themselves ever deeper into the hole created and subsequently entrenched by their L1" (Ellis, 2006, p. 185).

Another powerful argument for explicit phoneme training comes from a study entitled Phonetic Training Makes Word Learning Easier (Perfors \& Dunbar, 2010). This study shows that training on phonetic contrasts improves word learning. Perfors and Dunbar (2010) investigated how small differences in one aspect of language can have cascading effects that result in larger differences in other aspects of language. How might difficulties in phoneme perception be responsible for a poor performance on other aspects of language? L2 learners have difficulty processing fluent speech, which may be due to difficulty in perceiving the phonemes that make up that speech. Difficulties in rapid processing could also lead to difficulties in segmenting words and mapping those words onto their meanings.

In Japan there are also cultural reasons supporting explicit phoneme instruction. Teacher- centered classes are still the norm, so explicit pronunciation training is perhaps familiar and appropriate given the students' expectations. Improving listening skills also increases confidence and a sense of accomplishment. And finally, in a study by Jenkins (2005), when two non-native speakers communicate in English, mistakes at the phonemic level were the most common cause of communication breakdowns.

\section{The best techniques for phonemic training}

To the third question at the outset: What are the best methods for modifying L1 phoneme structure? A study by Zhang, Kuhl, Imada, Kotani, and Tohkura (2005) will serve as a model.

Zhang, et al. (2005), in a study with NTT in Tokyo, looked at whether Japanese listeners could be trained to respond to the / $\mathrm{r}-1 /$ stimuli as linguistic signals, that is, with the left hemisphere of the brain. The Japanese subjects heard numerous speakers produce / $\mathrm{r} /$ and / $/$ syllables containing contrastive minimal pairs and with greatly exaggerated duration. After twelve hours of training they showed over twenty percent improvement in discrimination. Also, MEG data revealed that the subjects treated the stimulus with the left hemisphere of their brains indicating that increased linguistic, as opposed to purely auditory, processing was involved.

Putting the phonemes in contrast is a tried and true technique. Signal enhancement stems from the need to make the signal audible (if you can't hear it, you can't learn it) and having numerous speakers is called "high variability." Studies using contrasting pairs and signal enhancement had shown success in improving learners' ability to distinguish difficult contrasts, but could not provide evidence that the training improved recognition of stimuli beyond the studies themselves. Logan, Lively, and Pisoni (1991) used the same techniques, but produced by multiple talkers, and the subjects improved significantly.

The question that arises is: What do these lab-based studies have to do with a classroom? When considering Zhang, et al. (2005), it is important to note that it dealt with native Japanese speakers and the English / $\mathrm{r}-1$ / contrast, the most difficult kind of contrast to acquire. When designing a teaching strategy for pronunciation, 
like when planning a grammar strategy, it is important to consider the nature of the learners' task in terms of difficulty and the chances of success.

Teachers need not choose such a difficult contrast, and the exposure need not be so intense. Teachers have students for semesters or an entire school year; departments have students a number of years. Enhanced exposure to phonemic contrasts can be worked into daily classroom activities, a syllabus, or a curriculum and given in communicative ways.

To reach a high variability threshold, audiovisual aids-a CD or DVD-might be necessary. Such an aid, moreover, could give confidence to non-native teachers who may be insecure about pronunciation practice. Also, those with access to computers can use computer-assisted language learning (CALL).

\section{Summary}

Using NLM-e as a conceptual model this paper discussed how infants create a sound map. It was shown how sound maps represent neural commitments that interfere with later language learning. Three questions were asked: 1) Can L2 learners' perceptual patterns can be modified after the initial mapping of native phonemes? It was shown that $\mathrm{CPH}$ is a variable phenomena and that plasticity remains into adulthood. 2) Is phoneme training worthwhile? It was pointed out that explicit instruction is the only way EFL learners will learn to perceive some non-native phonemes. Also, a study demonstrating how phoneme perception cascades to other abilities was discussed. Cultural reasons for explicit phoneme instruction were also given. 3) Which methodologies have proven to be most effective in modifying an L2 learner's initial L1 phoneme structure. The need to present phonemes in contrast, to make them salient, and to present them with "high variability" was noted.

\section{Note}

1. The Sounds of English < aka-kara.com> is an example of a DVD produced solely to teach contrastive phonemes.

\section{References}

Cheour, M., Ceponiene, R., Lehtokoski, A., Luuk, A., Allik, J., Alho, K., \& Naatanen, R. (1998). Development of language-specific phoneme representations in the infant brain. Nature Neuroscience, 1, 351-353.

Ellis, N. C. (2006). Selective attention and transfer phenomena in L2 acquisition: Contingency, cue competition, salience, interference, overshadowing, blocking, and perceptual learning. Applied Linguistics, 27(2), 164-194.

Jenkins, J. (2005). Implementing an international approach to English pronunciation: The role of teacher attitudes and identity. TESOL Quarterly, 39, 535-543.

Kuhl, P. K. (2000). A new view of language acquisition. Proceedings of the National Academy of Science, 97(22), 11850-11857.

Kuhl, P. K., Tsao, F. -M., Liu, H.M., Zhang, Y., \& de Boer, B. (2001). Language/Culture/Mind/ Brain: Progress at the margins between disciplines. In A. Domasio, A. Harington, J. Kagan, B. McEwen, H. Moss, \& R. Shaikh (Eds.). Unity of knowledge: The convergence of natural and human science (pp.136-174). New York: The New York Academy of Sciences.

Kuhl, P. K., Conboy, B. T., Coffey-Corina, S., Padden, D., Rivera-Gaxiola, M., \& Nelson, T. (2008). Phonetic learning as a pathway to language: New data and native language magnet theory expanded (NLM-e). Philosophic Transactions of the Royal Society (B 369), 979-1000.

Logan, J. S., Lively, S. E., \& Pisoni, D. B. (1991). Training Japanese listeners to identify English $/ \mathrm{r} /$ and /1/ : A first report. Journal of the Acoustical Society of America, 89(2), 874-886.

McCandliss, B. D., Fiez, J. A., Protopapas, A., Conway, M., \& McClelland, J. A. (2002). Success and failure in teaching the $[\mathrm{r}]-[1]$ contrast to Japanese adults: Tests of a Hebbian model of plasticity and stabilization in spoken language perception. Cognitive, Affective, $\mathcal{E}$ Behavioral Neuroscience, 2(2), 89-108. Retrieved from $<$ www.cnbc.cmu.edu / jlm/ papers / McCandlissETAL02.pdf $>$.

McClelland, J. L., (n. d.). How far can you go with Hebbian learning, and when does it lead you astray? Retrieved from <www.psychology. stanford.edu/ jlm/papers / McClellandIPHowFar.pdf $>$. 
Perfors, A., \& Dunbar, D. (2010). Phonetic training makes work learning easier. Proceedings of the 32nd Annual Conference of the Cognitive Science Society. Retrieved from $<$ www.psychology.adelaide.edu.au/personalpages/staff / amyperfors/ papers/ persordunbar10cogsciphonticlearinghelpwords.pdf $>$.

Werker, J. F., \& Tees, R. C. (1983). Developmental changes across childhood in the perception of non-native speech sounds. Canadian Journal of Psychology, 37(2), 278-286.

Werker, J. F., \& Tees, R. C. (2005). Speech perception as a window for understanding plasticity and commitment in language systems of the brain. Developmental Psychology, 46(3), 233-251. Retrieved Nov., 2008, from $<$ www.utdallas. edu/ assmann/ hcs6367/werker_tees05.pdf>.
Zhang, Y., Kuhl, P., Imada, T., Kotani, M., \& Tohkura, Y. (2005). Effects of language experience: Neural commitment to language-specific auditory patterns. NeuroImage, 26, 703-720.

\section{James Jensen has a Master of Arts Degree in Literature from the University of Cali- fornia at San Diego and a Certificate in Teaching English as a Second Language from California State University at Sacra- mento. He has taught at the university level} in Mexico, Spain and

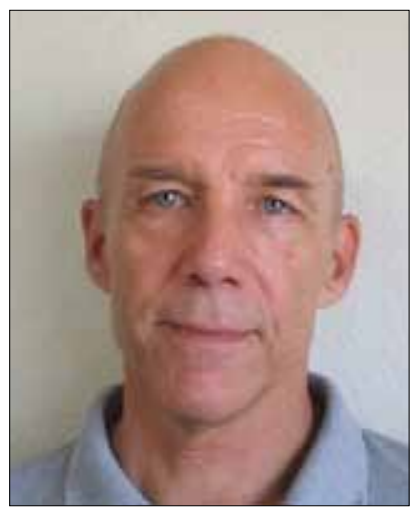
for over a decade in Japan. He is the founder of Aka-Kara English.

\section{JALT20 I I: Teaching, learning and growing}

\section{Featured Speakers}

This year a total of ten featured speakers come to JALT:

- Andy Boon investigates what the reflective teacher should be.

- $\quad$ Kip A. Cates will discuss Education for World Citizenship.

- $\quad$ Phillip Chappel will outline genre-based teaching and its relationship to developing oral skills.

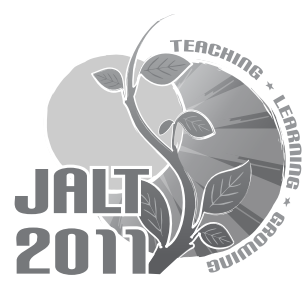

- Fiona Copland will look at examples of how young learners are taught around the world.

- Keith Johnston will discuss the essential skills that make up a great teacher.

- Kathy Kampa focuses on some important 'M' words, music, movement and multiple intelligence strategies for those teaching young children.

- Chris Kennedy will outline how to encourage students to unleash their creativity.

- Tom Kenny will tear down the myth that "conversation classes" are of low status and will propose a "feedback-oriented" approach to developing oral language skills.

- Theron Muller will explain how participants can become more involved in academic publishing and improve the chances of being published.

- Greg Sholdt will give an introduction to quantitative research providing a simple research design for teachers.

\section{Presentations and workshops}

While the 5 plenary speakers and 10 featured speakers command the large font size on PR materials, undoubtedly the heart of the conference is the over 400 workshops and presentations held by local and international language education practitioners. These provide a focus on many different areas of language teaching. Abstracts for all of them can be viewed at <jalt.org/conference $>$. The presentations also provide a great chance to meet people with similar interests and undoubtedly offer the potential for future partnerships and collaborations. Undoubtedly one of the highlights of any JALT conference for many is the opportunity to talk to like-minded (and sometimes not-so like-minded) teachers, researchers, students and well, people, who share their passion for teaching, learning, and growing. 